\title{
Phenomena or noumena? Objective and subjective aspects in knowledge organization
}

Preprint of the accepted final version of the paper published in "Knowledge organization", 43 (2016), n. 4, p. 239-253.

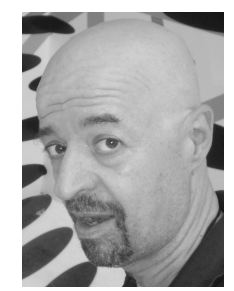

Riccardo Ridi

Università Ca' Foscari di Venezia, Dipartimento di studi umanistici, Dorsoduro 3484/D, I-30123 Venezia, Italy, <ridi@unive.it>

\begin{abstract}
Biography: Riccardo Ridi graduated in moral philosophy at the University of Florence and has been professor of library science at $\mathrm{Ca}$ ' Foscari University of Venice since 2000. He worked as an academic librarian from 1988 to 1999 and was the coordinator of the website of the Italian Library Association (AIB) from 1996 to 2008. He is a member of the editorial board of four Italian journals in the field of library and information science and he coordinated the drafting of the Librarians' code of ethics approved by AIB in 2014. At present his main research interests are digital documents, philosophy of information and library ethics. His homepage, featuring a full bibliography, is available at <http://www.riccardoridi.it $>$.
\end{abstract}

\begin{abstract}
This article examines the main objective and subjective aspects traceable in the concepts of information, document, knowledge, knowledge organization and level of reality. The hypothesis of the author is that objective and subjective aspects are both present in each of these entities, as it is sometimes implicitly recognized even by some of the authors that usually underline exclusively the objective or the subjective elements of these entities. "Moderate constructivism" is the synthesis of objectivism and subjectivism that consists in recognizing that reality is neither completely "given" nor completely "built" and it constitutes (beyond too marked pseudo-oppositions) the paradigm today de facto dominant both in epistemology studies and in knowledge organization studies.
\end{abstract}

Acknowledgments: This article, translated by Juliana Mazzocchi, derives from a lecture held by Riccardo Ridi and Claudio Gnoli in Bologna on April 20, 2015 at the 7th national meeting of ISKO Italy. A quite different version (Ridi 2015) was published in Italian with the title Livelli di irrealtà (levels of irreality). I would like to thank Francesco Dell'Orso, Claudio Gnoli and Alberto Salarelli for their suggestions and Michael Kleineberg for allowing me to read a work of his (Kleineberg 2016) in advance of publication. URLs were last checked on January 2, 2016.

Keywords: information, documents, knowledge, knowledge organization, reality, levels of reality, realism, irrealism, constructivism, solipsism, phenomena, noumena

"The sharp corner is reality, everything else can only be imagined"

(Cavazzoni 2015, 150).

\section{Foreword}

Objectivity and subjectivity are the two poles of a contraposition that goes through almost every aspect of human experience (Nagel 1979). To this pervasiveness the field of knowledge organization is no exception: sometimes in this there is a clash (especially at a theoretical level) and more often a meeting (at a practical level) between instances that underline how the way we organize information, documents and knowledge depends mostly on the way we see them and use them and other instances that instead insist on a certain degree of independence and "resistance" of these entities as regards points of view and purposes. But before dealing with this topic, it will be useful to start by making some remarks about the objective/subjective dialectics applied to the concepts of information, document and knowledge.

\section{Objective and subjective aspects of information}

Between 2005 and 2011, in some important international information science journals, a heated debate took place between Marcia J. Bates (2005, 2006, 2011), Professor of Information Studies at the Graduate School of Education and Information Studies, University of California and Birger Hjørland (2007, 2009, 2011), Professor of Knowledge Organization at the Royal School of Library and Information Science in 
Copenhagen. The issue of discussion was the concept of information. For Bates all "patterns of organization of matter and energy", that is to say any disposition, sequence or configuration (even accidental) of physical elements (such as the arrangement of pebbles on a beach or of ink on a page), could already be considered relevant to that concept (Bates 2005). Hjørland, on the contrary, underlined that it was meaningless to consider as proper information what (remaining at the mere physical level) cannot inform about anything until there is not a biological organism able to be informed or to acquire some form of knowledge by examining the patterns at issue.

This conflict, however, can probably be overcome by those unitary approaches (Hofkirchner 2010, Gnoli and Ridi 2014) to the various meanings of the term "information" that prefer to call "data", "configurations", "information atoms" or "potential information" the exclusively syntactic information represented by the patterns and to name, instead, "contextualized data", "significant data" or "actual information" the semantic information that emerges when patterns enter into relations with an organism, placing them in a reciprocal dialectic relation (Ridi 2010, 3-6). After all, using the words of Hjørland's (2007, 1449) (who, in turn, refers to the so classical as ambiguous definition of information by Bateson (1972, 271-272 and 315) "as a difference which makes a difference") the objectivistic approach, according to which "any difference is information", and the subjectivistic one, according to which "information is a difference that makes a difference (for somebody or for something or from a point of view)", can more plausibly be seen as two successive stages of the same process, both logical and chronological, rather than in a relationship of mutual negation (Hofkirchner 2010, 85-97).

On the other hand, Bates herself recognizes that "information exists both subjectively and objectively" (Bates 2015), that her work "contains ideas that mostly complement, rather than conflict with, those of Hjørland" (Bates 2011, 2038) and that "animals perceive data, not information" (Bates 2005), so much as to place information intended as "patterns of organization of matter and energy" (Bates 2005) at the basis of a pyramid of the various meanings of the term "information" taken from Goonatilake (1991) which also includes the following steps, semantically richer, of genetic, neural-cultural and exosomatic information (Bates 2006). And Hjørland himself, although he gives the utmost importance to the subjective aspects and to the social context of information, certainly does not assert that information is created ex nihilo from each organism in a totally inner and autonomous way (or, we might almost say, "oneiric" or " hallucinatory"). In fact, in his many works (among which Hjørland and Albrechtsen 1995, Hjørland and Hartel 2003, Hjørland 2010) dedicated to the various "knowledge domains" into which the human society is divided into, he has theorized a structuring of information not only in an epistemological and in a sociological dimension, but also in an equally important, ontological dimension, that concerns the objectivity of known phenomena as well as of the documents about them. And he even published an article in favour of the Arguments for philosophical realism in library and information science, in which he recommends to "not confuse reality with users' beliefs or preferences" (Hjørland 2004, 499).

\section{Objective and subjective aspects of documents}

As the discussion between Bates e Hjørland was used to exemplify the wider debate between the supporters of objectivity and subjectivity of information, so the discussion published in 2012 in the Italian electronic journal "Bibliotime" can help to synthesize the analogous contraposition traceable in literature about the nature of the material objects that "contain" or "convey" information, that is to say documents. On that occasion Claudio Gnoli (Pavia University), Paola Rescigno (Bologna University), Riccardo Ridi (Ca' Foscari University, Venezia) and Alberto Salarelli (Parma University), starting from the various definitions of "document" collected and commented by Buckland (1997), wondered whether the fact that a given physical object is legitimately considered a document depends (exclusively or predominantly) on some of its objective characteristics (such as the fact that it contains DNA or alphabetic signs) or on some social decisions (such as the fact that a human being decided to use it to distribute information or that a museum decided to accept it in its collections) or on the subjective capacity of single individuals to extract from it information that was recorded also unintentionally (as it can happen to those who examine a fossil or a crime scene).

Answering these questions each of the participants in the debate underlined the prevailing aspects that he/she found sometimes underestimated, remembering for example how only the objects especially created or modified by human beings for information or communication purposes are proper "native documents" 
(Gnoli 2012a), how the "constitutive power of places" (Rescigno 2012) deputed to the selection, conservation, organization and fruition of documents (archives, libraries, museums) plays an important role in their definition and identification, how "first of all the individual dimension has to be taken into account in the interpretation of the objects that populate the world" (Salarelli 2012) and how it is possible to distinguish between "intentional documents" and "unintentional documents" (Ridi 2012), categories that are, however, separate only by a socially and individually malleable boundary, and therefore mobile. Yet none of the participants went so far as to deny resolutely the relevance of at least some objective, subjective or social aspects in the individuation of documents. And reading that discussion again today, we can observe how it revealed that, paradoxically, the most unquestionably "objective" documents, produced by nature long before humans inhabited the Earth (like the seasonal growth rings of trees and the DNA), are often acknowledged as such only after individual or social discoveries. We can also observe that, equally paradoxically, the documents that have been universally considered as such since longer and to a greater extent and that are therefore included in the collections of archives, libraries and museums, are instead unquestionably "native" and "intentional" documents created by humans (and therefore in some way "subjective") like books and paintings.

Lastly, we can see how the same logical (and sometimes also chronological) gradation, detectable between the syntactic information (i.e. data) and the semantic information (i.e. knowledge), can also be found in documents. Any physical object is potentially (i.e. philosophically) a document, provided that it includes (or is included in) a pattern that marks "a difference", but it really becomes a document (that is that it begins to be treated as such) only when somebody or something "recognizes" the pattern and therefore uses the object itself as a document, as actually (i.e. pragmatically) informative (Ridi 2010, 10-14).

\section{New realism}

Much more extended (both chronologically and for the number of authors involved and the overall cultural impact) among the debates on the objective and subjective aspects of information and of documents is the discussion about the same aspects relating to human knowledge, which can be dated back at least up to the presocratic Greek philosophers and that counts among its characters figures like Plato, Aristotle, Descartes, Spinoza, Locke, Hume, Kant and Wittgenstein, just to mention a few names of the Western tradition. Therefore it is inevitable to be even more selective, simply summarizing those discussions through few texts of the last decades.

In this case too it may be useful to start from a very recent (still ongoing) debate (Santarcangelo and Scarpa 2015), initiated in 2011 by Maurizio Ferraris, Professor of Theoretical Philosophy at the Torino University, when he fulfilled a process of progressive distancing from his "subjectivistic" juvenile positions to get a more "objectivistic" position coining the effective label of "new realism", which, since then, he has been propagandizing in many publications (including De Caro and Ferraris 2012, Ferraris 2012). The fundamental thesis of new realism is that after decades of predominance, on the international philosophical scene, of theories about human knowledge that underline its uncertainty, its relativity and the unavoidable "constructive" elements introduced in it from the point of view of the knowing subject (variously articulated and denominated by a number of authors too large to be cited here such as "postmodernism", "constructivism/constructionism", "contextualism", "perspectivism", "relativism", "skepticism", "pragmatism", "logocentrism", "panlinguism", "panculturalism", "deconstructionism", "poststructuralism", "antirealism", "irrealism", "weak thought" or "transcendentalism", the latter not be confused with the homonymous nineteenth-century American literary movement of which Ralph Waldo Emerson and Henry David Thoreau were among the leading figures), the time has come to underline that an objective "unamendable" reality exists (Ferraris 2009, 86-88; Ferraris 2012, 34-37), which is independent from our points of view and "resistant" to our interpretations, the characteristics of which are perhaps not easy to identify and to describe exactly, but with which we must inevitably come to terms. In other words, after a long period with a predominance of epistemology, gnoseology and hermeneutics (which are the names with which, with nuances related to countries, languages and schools of thought, the subdisciplines of philosophy that deal with how and if it is possible to know the world are called) now metaphysics and ontology should be reevaluated, which are instead philosophical subdisciplines that deal with how and if the world exists and is structured (Ferraris 2009, 57-84 and 317-318; Ferraris 2012, 31-33). In other words, again, to Nietzsche's sentence (1887) "there are no facts, only interpretations" that for Ferraris $(2009,70-78 ; 2012,2)$ constitutes 
the fundamental thesis of the opposite front to new realism, one should reply by highlighting "the extremely broad spheres of reality that are independent of theories and of cultural conditioning" (Ferraris 2009, 81).

Nevertheless according to various authors, not at all impressed by Ferrari's realistic "conversion" (Veca 2012, D'Agostini 2013, Di Cesare et al. 2013, Totaro 2014), his argumentations are substantially based on the the straw-man rhetorical device, consisting in inventing a caricature of the opponent that is easier to refute, and his own positions are still largely imbued with the constructivism that he claims to have repudiated and that he wants to fight.

Which "realism" is a realism that is defined in opposition to an non-existent antirealism, never claimed by anyone? [...] And why on earth would the halfconstructivisim (not everything is construction, not everything is interpretation) be "realism": a very reasonable position, but epistemological and not metaphysical, and all in all already known to anyone? (D’Agostini 2013, 65).

\section{Solipsism}

As for the first critique made against Ferrari, perhaps no one in the entire history of Western philosophy (and, in any case, surely not in the last half century) has never gone so far as to deny that "something" independent of our mental schemes exists. Solipsism, that is the hypothesis that the world is only a sort of hallucination of the knowing subject, is a skeptical theory considered by many philosophers (including Descartes, Fichte, Schopenhauer, Husserl, Wittgenstein, Russell and Sartre), but only to reject it, although considering it at times theoretically unassailable from a strictly logical point of view (Thornton 2004; Mazzantini and Sacchi 2011; D'Agostini 2013, 131-137). Strictly speaking, not even the idealist George Berkeley (1685-1753), often mistakenly considered the champion of solipsistic irrealism, believed that his motto "esse est percipi" ("to be is to be perceived") involved the hallucinatory (or completely creative) character of human knowledge, thanks to the divine guarantee of its compliance with an external reality that coincides with the ideas present in God's mind (Downing 2011). Also the "anarchist" epistemologist Paul Karl Feyerabend (1924-1994), considered one of the most radical constructivists of the twentieth century, admits that "our entire universe [...] is an artifact constructed by generations of scientist-artisans from a party yielding, partly resisting material of unknown properties" (Feyerabend 1999, 224). Not even the nineteenth century German idealism of Fichte, Schelling and Hegel can be considered a form of irrealism or antirealism, because of its strong objectivistic component and of its acute awareness of the limits of the empirical human knowledge (Sedgwick 2000). Even the nihilistic thesis of Gorgias (485 AC - 375 AC) "nothing exists" (arrived to us, moreover, only through later testimonies) has been discussed for at least a century whether it is to be taken literally or is, rather, a confutation (or a parody) of Parmenides's thought (Migliori 1973, 157-202; Reale 2004, 71-82; Bonazzi 2010, 39-50). Not even the illusoriness of the empirical world typical of Eastern philosophies such as Buddhism, Hinduism and Taoism prevents that they involve a deeper and stable reality, called in various ways (Capra 1975, 130-131; Feyerabend 1999, 10-12).

Therefore, in order to trace forms of explicit and resolute theoretical negation of the "external world", we should carefully sound the history of thought both Western and Eastern, deepening the possible antirealism of philosophical positions that are in any case completely extraneous to postmodernism such as that of the seventeenth century French physician Claude Brunet (Mazzantini and Sacchi 2011, 10845) or the "actual idealism" of the Italian neoidealist Giovanni Gentile (1875-1944), who, according to some commentators, acts "the radical elimination of all the objectivistic elements that still remain in Hegelism" (D'Agostini 1999, 117; see also Severino 2014, 31), achieving "the negation of millennia of realistic thought, or of failed attempts to get out of realism" (Severino 2014, 21).

Most, if not all, postmodernist philosophers would therefore have no difficulty in agreeing with the neorealist thesis that "in very many cases, the sharing of a world depends much more on the characteristics of the objects than on the agreement of conceptual schemes" (Ferraris 2009, 81), rather emphasizing that there are also different cases and that the conceptual schemes nonetheless play an important role, and that Ferraris himself has to admit that "unlike ancient skeptics, postmodern constructionists do not doubt the existence of the world" (Ferraris 2012, 31). Even Nietzsche, if we contextualize the incriminated sentence within the fragment from which it was extracted (Veca 2012, 520-523; D'Agostini 2013, 34-45; Gemes 2013, 557; Totaro 2014, 101), actually distances himself both from the most radical objectivism and subjectivism, showing how interpretations are the meeting place of both those instances and questioning not 
so much the existence of "facts" but rather that of inaccessible "facts in themselves", of which not even the most radical realist could state anything beyond the mere assumption of existence.

\begin{abstract}
Against positivism, which halts at phenomena — "There are only facts" — I would say: No, facts is precisely what there is not, only interpretations. We cannot establish any fact "in itself": perhaps it is folly to want to do such a thing. "Everything is subjective," you say; but even this is interpretation. The "subject" is not something given, it is something added and invented and projected behind what there is. - Finally, is it necessary to posit an interpreter behind the interpretation? Even this is invention, hypothesis.

In so far as the word "knowledge" has any meaning, the world is knowable; but it is interpretable otherwise, it has no meaning behind it, but countless meanings . - "Perspectivism."

It is our needs that interpret the world; our drives and their For and Against. Every drive is a kind of lust to rule; each one has its perspective that it would like to compel all the other drives to accept as a norm (Nietzsche 1887).
\end{abstract}

Not to mention the other almost coeval passage in which, after expressing a similar thesis, Nietzsche himself admits that this too is, after all, only an interpretation, refusing to attribute to it an excessive explanatory claim (Nietzsche 1886, aphorism 22; D'Agostini 2013, 34).

On the other hand Ferraris himself $(2009,73)$ admits that "the disparity between the situations brings out the difference between the sphere of the sciences - the search for absolute truth - in which the claim that there are no facts, but only interpretations might make some sense, and the sphere of life and experience, where such a thing makes no sense whatever", an observation that probably Nietzsche himself would accept, since he expressed his thought (published posthumously, by the way) philosophizing and not having a conversation in a pub.

\title{
6. Natural, ideal and social objects
}

For the second critique, Ferraris's theses are "argumentations under which lies a logic similar to the one present in most of postmodern speeches" (Veca 2012, 521) and the basic thesis that Ferraris proposes is, by his explicit admission, "a modest or minimalist realism" (Ferraris 2012, 48), that is to say a "moderate constructionism" (Ferraris 2012,102), which is shaped more like "a "treaty of perpetual peace" between the realist insight and the constructionist one" (Ferraris 2012, 63) rather than like an innovative and invincible argument able to finally defeat any form of skepticism and relativism. In fact Ferraris divides the world in three big categories of objects: natural, ideal and social (Ferraris 2009, 32-54), building around the social ones a whole philosophy of documentality ("Papers, archives, and documents constitute the fundamental element of the social world. Society is not based on communication but on registration, which is the condition for the creation of social objects" Ferraris 2009, 319), in which the postmodern constructivism is totally included, with a integrating and founding role.

In the world of social objects [...] belief determines being, given that these objects depend on subjects. [...] While transcendentalism is not applicable to natural objects, it fits social objects perfectly. The Kantian thesis that intuition without concepts are blind does not apply to lakes and storms (which remain as they are independently of our conceptualizations), but it does apply to mortgages and conferences. [...] Naked life is nothing but a remote starting point, and culture begins very early making for a clothed life, which is manifested in registrations and imitations: language, behaviors, and rites (Ferraris 2009, 318-319).

As for natural and ideal objects (assuming that it is obvious to distinguish them from the social ones), which should, at least themselves, be completely immune from constructivism, but which nonetheless are strangely less central than the social ones in Ferraris's works even after his neorealistic conversion, one could, however, doubt their independence from the human gaze since Ferraris (2009, 34-35) declares that he considers "natural" the objects that can be met in ordinary experience and not the objects described by science (as if only science were contaminated by changeable theoretical constructs while ordinary experience allowed a direct access to things "in themselves", stably universal and not oriented by social, cultural or personal prejudices) and that he calls "ideal" those entities that, like numbers, "exist outside time and space independently of subjects" (Ferraris 2009, 38), but the numerous social applications of which cannot but share the issues of the corresponding typology of objects.

In addition to natural, ideal and social objects, to complete Ferraris's "catalog of the world" (2009, 7-54), there are also those "subjects", defined as "individuals whose prime characteristic is to have a central 
nervous system that is sophisticated enough to capture and fix representations" (Ferraris 2009, 22), which makes us think that they are, all things considered, only a particular typology of natural objects.

\title{
7. Irrealism, hyperrealism and "moderate" realisms
}

The contrast between neorealists and postmodernists is made less sharp than Ferraris depicts it also by the particular consonance of the theses of two philosophers who should rather militate on the opposite sides of that conflict of ideas. On one side there is the American philosopher Nelson Goodman (1906-1998), who in his classic book of 1978 Ways of worldmaking defines his own position as "a radical relativism [...] that eventuates in something akin to irrealism" (Goodman 1978, x), since the fundamental thesis of the volume, synthesized by the editor of the Italian edition is that

\begin{abstract}
there is not one world; there are many worlds, none of which all-inclusive. More precisely, there is one world for each different way to combine and build symbolic systems. There is one world for each version and vision of it in the different scientific theories, in the works of different artists and novelists, in our perceptions as influenced by those works and theories in addition to the circumstances, the past experiences, the interests that guide us, by our observation capacity and so on.

Since for Goodman these different versions or visions can be equally important and independently interesting, even correct, without having to presume or request their reducibility to a single common basis, it follows that the worlds that derive from them have the same degree of reality: no world can arrogate to itself the exclusive right to the title of "real world", no one can claim to be the world to which the different versions refer to with different languages and modalities (Varzi 2008, pix-x).
\end{abstract}

On the other side is the young German philosopher Markus Gabriel, who, in his recent volume with the surprising title (especially for a declared follower of Ferraris's "new realism") Why the world does not exist (Gabriel 2013), does not support the inexistence of the material universe described by astronomy and physics, but rather the inexistence of an hypothetical totality that includes not only physical objects but also "a good number of objects [...] which man cannot touch" (Gabriel 2013,8) like our thoughts, national states, unrealized possibilities and numbers. For Gabriel, each of these objects exists, but only within a "field of sense" (Gabriel 2013, 65-72) that connects it with many other objects, but never with all of them, because each field of sense (also called "object domain" or "ontological province" at page 49) corresponds to a particular perspective, which at the same time includes and excludes certain types of objects. Numbers exist in the field of sense of mathematics, rhinos in the field of biology, unicorns in the field of mythology, thoughts in the field of psychology, but there is not a single field of sense (a "domain of all domains", Gabriel 2013, 73) that contains them all and that we could really consider "the world", that is to say "the whole" (Gabriel 2013, 18), because, in order to exist, it would, in turn, need to appear in a wider field of sense, with a paradoxical effect of infinite regress.

The two theories are different, because the first one multiplies the worlds, while the second one does not recognize even one, but their points of contact are, however, considerable, because both of them doubt that there is an only all-inclusive reality, proposing in its place innumerable different realities, incommensurable with one another. Goodman presents his own theory as an "irrealism" (Goodman 1978, x), Gabriel as a "new realism" (Gabriel 2013, 1), but both theories could perhaps be best classified as forms of "hyperrealism", alluding with this term (unrelated to its various meanings in mathematics, semiotics, music and visual arts) to a sort of multiplication and enrichment of reality and of admission of its inexhaustible polyhedricity. In any case Goodman's supposed irrealism is not so extreme as to become nihilism (or "trivialism, that is to say that everything is true, everything is fine, legitimized by the end of legitimizing discourses", D'Agostini 2013, 86), justifying the creation, by human beings, of any world, because he "refused to consider each construction of the world equally good: there would be correct constructions and incorrect constructions, and this depends on their conformity with the purposes for which they are used and on their practical effectiveness" (Magni 2010, 57; see also Chiodo 2006, 98-104). That is to say, in Goodman's words, his is "a radical relativism; but severe restraints are imposed" (Goodman 1978, 94). And Gabriel's neorealism, at the very moment he admits the relevance of scientific disciplines and of personal points of view for identifying the different fields of sense, cannot leave out of consideration elements of constructivism, whether he admits it or not.

Gabriel and Ferraris are also in good company in not being able to free themselves completely from constructivism, because all the authors (Akeel Bilgrami, Mario De Caro, Michele Di Francesco, Umberto 
Eco, Maurizio Ferraris, Diego Marconi, Hilary Putnam, Massimo Recalcati, Carol Rovane, John Searle) that contributed to a miscellaneous volume (De Caro and Ferraris 2012) that, in the editors' intentions, highlighted on the back cover, should have provided "an extraordinary battery of arguments in favour of realism, but also giving space to dissenting voices", turn out to be (some more and some less, but no one excluded) moderate constructivists, that is thinkers that give an important, but never exclusive, role to social, cultural, anthropological, linguistic and personal points of view in delineating the way we know the world. So much so that, after reading the book, we have the impression of having attended, rather than an epic reckoning against postmodernism, an interesting but subtle discussion within the postmodern movement itself, about which and how many constructivist elements are ineliminable from contemporary epistemology, and not about their complete elimination.

In this regard, Eco's position is exemplary; although not citing them explicitly, he refers to Popper's (1935) falsificationism (a theory is scientific only if it is possible to construct an experiment which could prove its falsity), to Poincaré's (1902) conventionalsim (scientific theories are conventions, but not arbitrary) and to Goodman's $(1984,31)$ radical but not nihilistic relativism ("a true version is true in some worlds, a false version in none") in order to propose a "negative realism" according to which

any interpretative hypothesis is always revisable (and, as Peirce said, it is always exposed to the risk of fallibility) but, if we can never say definitely if an interpretation is right, one can always say when it is wrong. There are interpretations that the object to interpret does not admit. [...] Certainly our representation of the world is perspectic, connected to the way in which we are biologically, ethnically, psychologically and culturally rooted so that we never believe that our answers, even when they appear, after all, "good", must be considered definitive. But this fragmentation of the possible interpretations does not mean that everything goes. In other words: there is a hard core of the being, such that some things that we say about it and for it cannot and must not be taken as valid (Eco 2012, 105-106).

Besides, independently of the debate on Ferraris's and Gabriel's "new realism", we can also mention other forms of sophisticated contemporary realism. They accepted the Humean (Lecaldano 2007) and Kantian (Ferrini 2007) critiques that irreversibly demolished the classical realistic claim to know appropriately an external world completely independent from our gaze and therefore they came to terms, to some extent, with some elements of constructivism. Franz M. Wuketits (1990), for example, proposes an "hypothetical realism" which links to the evolutionary epistemology of Karl Popper (1972), Konrad Lorenz (1973) and Donald Campbell (1974). Wuketits underlines how our perceptive and knowing apparatus is the result of a very long natural evolution and thus binds us to unavoidable biological limits. But, for the same reason, it is also very likely that is provides us with an idea of the external world realistic enough to allow us to survive, reproduce and, in fact, evolve. On the contrary, Roy Bhaskar's "critical realism" (Bhaskar 1979, Budd 2010) opposes both to the ingenuous realism of positivism and to the radical constructivism of postmodernism, trying to combine a realistic ontology with a relativistic epistemology through the concept of depth of reality, which our knowledge can penetrate more or less deeply but never completely ${ }^{1}$.

\section{Objective and subjective aspects of knowledge organization}

Moving from the analysis of the limits and the conditions of human knowledge in general to the analysis of a particular type of second-level knowledge which is knowledge organization itself, we often wondered if it is better, in order to classify and index objects, people, institutions, concepts, documents and information, to use categories based on an ontological approach (that is on the characteristics of the entities that we want to order), on an epistemological approach (that is on the way we know those entities), on a pragmatic approach (that is on the kind of use we want to do both of the entities themselves and of their various arrangements) or, more likely, on varied combinations and alternations among these approaches (Gnoli 2008, 77-99; Ridi 2010, 90-97).

For example, recently Kleineberg (2013) started from the ancient Indian parable of the blind men that, touching the different parts of a single elephant, give completely different descriptions of it,

\footnotetext{
${ }^{1}$ For Eco's negative realism and other forms of "moderate" contemporary philosophical realism see chapter Strani realismi of D'Agostini (2013, 139-146). Further forms of contemporary philosophical realism are mentioned by De Caro and Ferraris (2012, $\mathrm{x}$-xi) and others are discussed in the other chapters of D'Agostini (2013).
} 
incommensurable with one another, to illustrate the positions of the two opposite fronts that have been facing in the international studies of the past decades about knowledge organization. On one side are "modernists", that underline how the elephants is, after all, only one, and therefore it must be possible to integrate its various descriptions (different because partial) in a single picture, that focuses on the "what" of knowledge. For this "ontological" approach to knowledge organization "a main goal is to classify the totality of entities or phenomena in a universal and often faceted knowledge organization system (KOS) as neutral and objective as possible" (Kleineberg 2013, 341). Inversely, for "postmodernists", each blind man has not simply a different (partial) access to the same elephant, but he produces, through his own experience, a type of different elephant, just as real and complete as the one of the other blind men. The "development of context-transcending or even universal KOS's is regarded rather skeptically" (Kleineberg 2013, 341) by those who prefer this "epistemological" approach, that focuses on the "who" of knowledge and on its historical, cultural and psychological background.

Kleineberg considers incomplete both these approaches and proposes to integrate them, using KOS (knowledge organization systems, that is to say structured and controlled lists of terms used to organized, manage and search for information, documents and knowledge in a particular field or for a particular purpose, described for example by Zeng 2008 and Gnoli 2015) which take into account both the "what" and the "who" of knowledge, and, in addition, also the "how", that is to say the methods used in cognitive investigations, trying, in this way, to satisfy at the same time, both the ontological approach and the epistemological and the methodological ones. Kleineberg's attempt at synthesis is certainly commendable and goes in the same direction in which this article is moving, that is to say the ascertainment of the difficulty in separating clearly the objective and the subjective aspects of knowledge organization, not to mention the possible claim to eliminate completely one of the two, so much so that not even all the authors selected as representative of the modernist or postmodernist approaches always maintain consistently that position, as Kleineberg $(2013,341)$ himself admits. At most, one could perhaps raise doubts of a "financial" kind about the costs of indexing procedures that take into account so many aspects and one could note that the choice of the parable of the blind men is a little too oriented towards the "ontological" front, at least as much as it would have been to take as an example in favour of the "epistemological" front the assistant of an illusionist, seemingly sawn in half that, however, at a closer examination would prove to be, instead, two different women, only one half of each is visible.

Not too dissimilar from Kleineberg's "ecumenic" proposal (2013) is Gnoli's (2012b). Gnoli starts from the "ontological" exhortation of the León manifesto (ISKOI 2007) to use phenomena (rather than disciplines, as it occurs mainly in most current systems) as basic units of KOS and enhances it, providing (tab. 1) six "dimensions of knowledge organization" (the elusive reality in itself, phenomena, the perspectives from which phenomena are faced by human beings, the supports that carry the corresponding information, the collections of documents in which knowledge is recorded and preserved, and in the end the homogeneous groups of users that use those documents), studied by six corresponding disciplines or groups of disciplines (mysticism, ontology, epistemology, bibliology, library science together with archive science and museology, sociology).

\begin{tabular}{|l|l|l|}
\hline$\alpha$ & (reality) & [mysticism?] \\
\hline$\beta$ & phenomena & [ontology] \\
\hline$\gamma$ & perspectives & [epistemology] \\
\hline$\delta$ & carriers & {$[$ bibliology] } \\
\hline$\varepsilon$ & collections & {$[$ library science] } \\
\hline$\zeta$ & users & [sociology] \\
\hline
\end{tabular}

Table 1. Dimensions of knowledge organization according to Gnoli, taken from Gnoli (2012b, 270).

It is worth noting, as to the conclusions (sect. 11) of this article, that Gnoli, one of the authors cited by Kleineberg (2013) as particularly representative of the modernist trend in the studies of knowledge organization, includes in his pattern also the epistemological dimension, typical of the postmodernist trend, as it contains "the disciplines, [...] the domains addressed by different research communities, the human activities to which knowledge is intended to be applied, the communicative functions performed in transmitting knowledge, the theories adopted and methods applied, the historical epoch and geographical 
context in which knowledge is produced and, in general, all viewpoints adopted by authors" (Gnoli 2012b, $271)^{2}$. Consistently with this "multidimensional" opening, Gnoli himself, during the final debate of the ISKO meeting in Bologna on 20 April 2015, accepted the possibility of adding even a seventh "dimension", relating to the objectives, preferences, habits and constraints of individual users and to the characteristics of different and changing information needs and behaviours of each of them, studied by psychology and information science.

Inversely (and just as significantly) the postmodernist (again according to Kleineberg 2013) Hjørland, although he believes that "concepts of phenomena (etc.) are theory dependent and interest-dependent" (Hjørland 2008, 338) because "a neutral position from which the world can be observed objectively" does not exist (Hjørland 2008, 337; see also Nagel 1986 and Ridi 2010, 90-94) and therefore "all interpretations are circular, indeterminate, and perspectival" even when we are "describing and classifying phenomena in the world", he concludes that he does not believe that "this leads to skepticism or antirealism, because some theories do a better job than others" (Hjørland 2008, 338). This is a concept that he reaffirmed and examined closely in a very recent article (Hjørland 2015) in which he demonstrates the strict reciprocal dependence between theories and KOS, even more relevant for knowledge organization if we think that "even every-day concepts [...] are theoretical constructions and have theoretical implications for how we think and act" (Hjørland 2015, 114) and that "often what has been considered "facts" later turns out to be a theory" (Hjørland 2015, 116). Therefore Hjørland's constructivism and postmodernism do not prevent him from acknowledging that neither all theories nor all KOS perform equally well their task in describing and organizing the world or its parts, admitting thus implicitly that "out there" there must be something independent from them that helps us to compare their efficacy.

\section{Objective and subjective levels of reality}

A concept that may be particularly useful to focus the difference between objectivistic and subjectivistic approaches to knowledge organization is that of "levels of reality" (Gnoli 2006; Poli 2007; Gnoli and Ridi 2014, 450-453), used by various KOS of objectivistic kind, among which the Information coding classification (Dahlberg 1982) and the Integrative levels classification (ISKOI 2004), as a backbone to connect to one another, at the same time in a coherent but not reductionist way, all the entities that KOS themselves aim to classify. According to this approach, present in innumerable variants in the history of philosophy and science at least since Plato, all that exists is part of a unique hierarchical "great chain of being" (Lovejoy 1936) ranging from simple to complex and admitting no voids. In the twentieth century the prevailing version of this idea was the concept, influenced by Darwin's theories and by other forms of evolutionism, of "emergent" or "integrative" levels of reality. These are successive layers (in a logical and, at times, also chronological sense) of entities increasing more and more complex and autonomous, provided with characteristics absent in the previous layer but that emerge as truly innovative, although based on them, such as the case of chemical properties compared to physical ones and of biological properties compared to chemical ones (Juarrero and Rubino 2008). Among the philosophical theories on the emergent levels of reality that mainly influenced the most recent studies in knowledge organization, it is worth remembering Nicolai Hartmann's (1882-1950), which provides a stratification of reality in four levels (inorganic, organic, psychic and spiritual) autonomous and irreducible among them but resting on one another in order to exist (Hartmann 1940, Scognamiglio 2008).

But there is also (at least) another meaning of the expression "levels of reality": it is the one to which the title of the homonymous conference (Piattelli Palmarini 1984) held in Florence in 1978 refers. On that occasion some twenty philosophers, logicians, psychologists, psychiatrists, biologists, paleontologists, historians, linguists and writers (including, in addition to the same Piattelli Palmarini and the abovementioned Goodman e Putnam, also Alfred J. Ayer, Stephen J. Gould, Ronald D. Laing and Italo Calvino) met to discuss on how one should interpret the reality dealt, in one way or another, by their traditions of studies. They found that not only each discipline, form of knowledge, school of thought or single theory has to do with a reality different from the others (the summation of which breaks down the overall reality into a series of levels mutably manifold and scarcely integrable in a single model), but that even some of those points of view build worlds provided, in their turn, with some kind of articulation

\footnotetext{
${ }^{2}$ For further comments on Gnoli (2012b) and on Kleineberg (2013) see Gnoli et al. (2016) and Kleineberg (2014).
} 
(obviously always different and only at times of the emergentist kind) in layers or levels. There were no knowledge organization specialists among the speakers, but it is easy to imagine what could be (given the strong links between theories and KOS discussed in section 8) the impact in knowledge organization studies of this kaleidoscopic and labyrinthine exponential multiplication of the levels of reality, that leads to extreme consequences the "hyperrealist" approach described in section 7.

The ontological approach to the levels of reality (which would constitute layers objectively connected between them in a univocal and stable way) and the epistemological one (in which the levels are built by the way in which reality is "cut out" by the various observers and therefore the same levels change over time and are incommensurable with one another) seem totally incompatible (Poli 2007, 33), but again Kleineberg, in a recently published paper, makes us suspect that they are not that much. Kleineberg (2016) begins his essay illustrating (fig. 1) the stratification of reality theorized by Hartmann (1940). Then he applies to it a series of formal transformations, some of which are taken from Poli (2001), that progressively move away from the linearity of the original pattern and introduce patterns in which a plurality of upper layers co-evolve from a lower layer. Then Kleineberg arrives (fig. 2) to the pattern proposed by Wilber (2000), rather complex, if not even baroque, in its elegance but which has the merit of supporting a hypothesis of solution of the millenarian philosophical problem of the relationship between mind and body (Nannini 2011), at least original, referring to the ancient tradition of panpsychism (Skrbina 2005), that Wilber tries to make compatible with contemporary science.

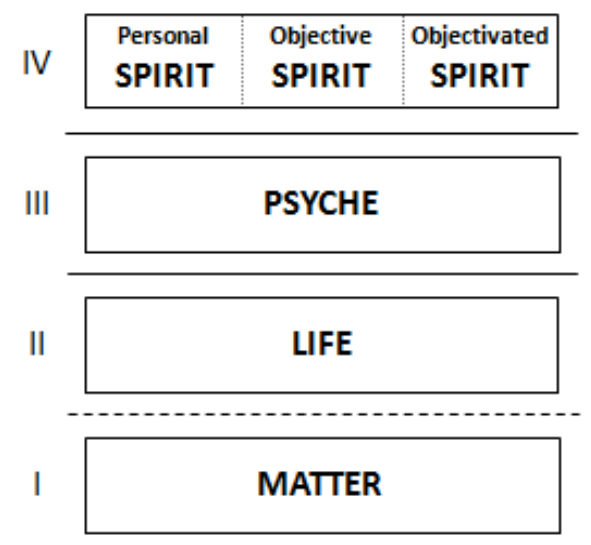

Figure 1. Levels of reality according to Hartmann, taken from Kleineberg $(2016,84)$.

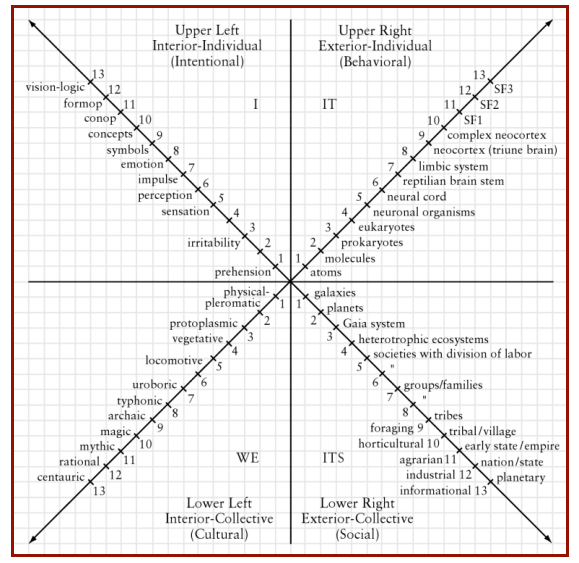

Figure 2. Levels of reality according to Wilber, taken from Wilber $(2000,198)$.

Both Hartmann's (1940) and Wilber's (2000) patterns are intended by their authors as ontological, that is as attempts to describe the real structure of the world, apart from out points of view, but the formal procedures of transformation used by Kleineberg (2016), whose incipit, moreover, refers to levels of reality as a "metaphore", and the multiplicity of the intermediate patterns elaborated during the transformation itself cannot but convey to readers a particular "epistemological" taste of the operation, also independently of the 
will and the opinions of its creator. On the one hand, therefore, ontological levels of reality could also be seen as epistemological levels of reality but, on the other hand, why not assume (at least in principle) the possibility of an ontological structure of levels so articulated as to absorb in its inside also all the levels of epistemological kind? After all, the prevailing theory today of a physical world that includes billions of consciences, is not stranger, from a strictly logical point of view, than the theory of a single conscience that contains the entire physical universe.

\section{Phenomena and noumena}

As we have seen, in each of the examined concepts (information, document, knowledge, knowledge organization, level of reality) there are aspects both objective and subjective, as indeed even some authors that are often considered intransigent objectivists or subjectivists are forced to admit, not only because of possible contradictions intrinsic to their own theories as rather for the unavoidable complexity of the issues that they would like to solve. Such a coexistence is accomplished in different ways and in varying proportions within each of the examined concepts, all, by the way, closely intertwined. For example, at a metaphysical level, an extreme irrealism is difficult to sustain, because even the most radical construtivists admit that in any case there must be "something" that put up resistance to human knowledge that would otherwise be purely hallucinatory. At a practical level, instead, a position which would not be totally unacceptable is that of those who maintain that any type of KOS must be judged, after all, only on the basis of its social utility or, in any case, of its efficacy in solving specific information problems, because KOS are basically nothing but tools invented by human beings to improve their lives.

Besides, not even radically solipsistic scenarios like the one imagined (in order to confute it) by Putnam (1977) and made popular by the film Matrix ${ }^{3}$ ("Are we brains in a vat, connected to a computer that provides us with the experience of reality?", D'Agostini 2013, 131-132) exclude the existence, at least, of a brain, a vat and a computer. And even Gorgias's possible nihilism ("Nothing exists. Even if something exists, nothing can be known about it. Even if something can be known about it, knowledge about it can't be communicated to others", see Reale 2004, 71-82) presupposes the existence of Gorgias himself. So much so that some defined realism a "non-controversial question" (D’Agostini 2013) because it it impossible to deny, keeping a minimum of logical consistency, that some kind of reality exists, and, in case, the controversy may rise only on what is deemed real and on how reality and our knowledge of it are structured. This latter question is not at all trivial, because "all that reaches us from the world are a few rays of light hitting our retinas, and a few air molecules vibrating at our eardrums - images and echoes. So how can we really know anything about the outside world? Where do our theories of the world come from and how do we get them right?" (Gopnik 2009, 75-76). Starting from so minimal sensory data it is hard not to foresee in the solution of the riddle some kind of role, not minimal this time, of our knowledge structures.

If, as the philosopher and mathematician Alfred North Whitehead (1861-1947) wrote, "the safest general characterization of the European philosophical tradition is that it consists of a series of footnotes to Plato" (Whitehead 1929, 39), it is likely that the epistemology and the ontology of the last two centuries are, in turn, footnotes to that important footnote to Plato that is Immanuel Kant's Critique of pure reason (1781/1787). In this work Kant demonstrates on the one hand the impossibility for human intellect of knowing "noumena", namely "things-in-themselves" as they are, independently of our gaze and, on the other hand, that "phenomena", namely the only objects that we can really know, are strongly influenced by the fundamental and universal structures, both necessary and unavoidable (called "transcendental") of any possible knowledge of a human being. Much of the epistemology and of the ontology after Kant (including those that found, often tacitly, the studies on knowledge organization) can be reduced to phases of a long debate on the nature of those phenomena: are they mere appearances, compared to the authentic and unattainable reality constituted by noumena, or are they the only existing reality, relegating noumena to mere borderline cases, totally hypothetical as knowable only by a possible divine intellect? It is not easy to answer once and for all to this question, also because even Kant oscillated between a "realist" position in which he seemed to interpret phenomena as an appearance (in the first edition of the Critique, of 1781) and a

\footnotetext{
${ }^{3}$ On the philosophical aspects of the three films of the series (The Matrix, 1999; The Matrix reloaded, 2003; The Matrix revolutions, 2003), all written and directed by brothers Andy and Larry/Lana Wachowski, see Irwin (2002 and 2005$)$ and Cappuccio (2004). On the Cartesian roots and the philosophical fortune of the "brains in a vat" see Davies (2004).
} 
"constructivist" position in which he instead interpreted them more decisively as reality (in the second edition, of 1878). There are even some critics who attribute to a different interpretation of Kant the great division in contemporary culture between "analytic philosophers" (who consider Kant as a constructivist) and the "continental philosophers" who consider him a realist (D'Agostini 2013, 108-112).

\section{Conclusions}

The discussion on noumena and phenomena is neither purely academic nor exclusively philosophical, because from the position taken in this debate, different trends may derive as regards each of the topics dealt with in this article and also a different nuance may arise in the way one can identify and call the coexistence of objective and subjective aspects that has emerged in relation to each of them. It is therefore possible that the fact that today there are so many ways (and names) to describe that coexistence depends also on a different interpretation (more or less aware) of Kant. For example, I should define as "moderate constructivism" (or, if you prefer, "realistic constructivism") the synthesis of objectivism and subjectivism that consists in recognizing that reality is neither completely "given" nor completely "built" and that it constitutes (beyond too marked pseudo-oppositions) the paradigm today de facto dominant both in epistemology studies and in knowledge organization studies. Dux (2011) instead prefers to speak (reverting the concepts) of "constructive realism", Eco (2012) of "negative realism", Wuketits (1990) and Gnoli (in Bologna) of "hypothetical realism" based on the assumptions that have so far passed the scrutiny of natural selection and Hjørland (2004) finally opts for a "pragmatic realism". This latter would mean to recognize both that "our ontologies are implied by our theories and paradigms" (Hjørland 2004, 492) both that "we cannot freely invent arbitrary structures" (Hjørland 2004, 492), because "the world provides "resistance" to our conceptualizations in the form of anomalies, i.e., situations in which it becomes clear that something is wrong with the structures given to the world by our concepts" (Hjørland 2004, 492). Hjørland (2004, 492) attributes this position also to the famous epistemologist Thomas Kuhn (1922-1996), yet acknowledging that often such a position is instead considered antirealist.

In any case, beyond nuances, denominations and the attempt of both the opposite fronts to annex the moderate intermediate position, I believe that this approach may share the same aspirations to the synthesis between the ontological and epistemological needs expressed by Kleineberg (2013) as to his own theory of knowledge.

In combining epistemology and ontology, this theory of knowledge seeks to integrate both the undeniable constructivism of human knowledge as well as its capability to reflect reality which is seen as partially independent from a human observer. In other words, neither the premise of pre-given ontic structures nor the premise of arbitrary epistemic constructions of reality are required, two extreme positions also known as the "myth of the given" invented by Wilfried Sellars and the "myth of the framework" coined by Karl R. Popper (Kleineberg 2013, 349).

But it is not given that such aspirations are actually satisfied by the theories currently available in the fields of philosophy and knowledge organization (including Kleineberg's and the one drafted in this article) because this would mean that they had finally managed to solve convincingly a problem that has lasted since Presocratics times and that was reformulated in modern times by a post-Kantian bipolarization which is extremely difficult to escape from, also because it permeates deeply our own language. This bipolarization tends both to make anyone who reflects on these issues to take sides with an objectivistic or subjectivistic position and to attribute one of those position also to the theories that, in one way or another, would rather overcome their opposition, as the readers of this article and Kleineberg's (2013) probably will do.

While waiting for a really persuasive theory of synthesis to emerge, maybe in the wake of Thomas Metzinger's (2009) reflexions, referable in turn to the empiriocriticism of Ernst Mach (1838-1916) and Richard Avenarius (1843-1896) and to Edmund Husserl's (1859-1938) phenomenology ${ }^{4}$, on the experience as a sort of neutral film between objectivity and subjectivity similar to the walls of a tunnel, what one can pragmatically do is to accept that "the coexistence of conflicting points of view, varying in detachment from the contingent self, is not just a practically necessary illusion but an irreducible fact of life" (Nagel 1979,

\footnotetext{
${ }^{4}$ See Smiraglia $(2012,12-13$ and $2014,28-29)$ for an introduction to phenomenology's relevance to knowledge organization studies and Budd (1995 and 2001) for the proposal of an epistemological foundation of library and information science on phenomenology.
} 
213) and that "perhaps we are really doomed to be two-tier thinkers (thinkers at two levels: both realists and relativistics)" (Piattelli Palmarini 1984, 524), striving to use the term "objective" and "subjective" only in a relative and not in an absolute way ("this is more objective/subjective than that one") as we usually do for couples like "tall/short", for which sentences like "that child is tall" are commonly and correctly understood as abbreviations of "that child is taller than most children of his age".

Besides, it will always be useful to remember that knowledge organization (as mentioned in sections 2, 3 and 8) needs or, otherwise, takes advantage of approaches not only ontological and epistemological but also sociological. In some way they mediate between objectivity and subjectivity underlining how KOS not only organize something and do it from certain points of view, but for the most they follow modalities and aims shared within social groups more or less large, if they do not want to be relegated into irrelevance and condemned to unsustainability, although without excluding completely the justification also of forms of knowledge organization for their own sake (Gnoli 2013) or for strictly private use (Jones and Teevan 2007).

In this way, rather than feeding a sterile debate between the positions of ingenuous "pure realists" and phantom "pure irrealists" (both in fact absent from the pages of the contemporary journals of both philosophy and knowledge organization studies) we could all accept that there are both facts and interpretations (D'Agostini 2013, 40) and discuss more calmly and more profitably on how many and which (more) objective and (more) subjective elements are involved in each specific knowing situation or are useful in each specific KOS. And perhaps we all could also share and apply also to KOS what Eugenio Lecaldano (1987) wrote about philosophical theories, summarizing Bernard Williams's (1985) position, that is to say that they "can be considered as large-mesh nets built to try to grasp the world, with the awareness that much will remain out and that others, quite legitimately, will cast different nets".

\section{References}

Bates, Marcia J. 2005. Information and knowledge: an evolutionary framework for information science. Information research 10n4. Available http://informationr.net/ir/10-4/paper239.html.

Bates, Marcia J. 2006. Fundamental forms of information. Journal of the American society for information science and technology 57n8: 1033-45.

Bates, Marcia J. 2011. Birger Hjørland's manichean misconstruction of Marcia Bates' work, Journal of the American society for information science and technology 62n10: 2038-44.

Bates, Marcia J. 2015. The information professions: knowledge, memory, heritage, Information research 20n1. Available http://InformationR.net/ir/20-1/paper655.html.

Bateson, Gregory. 1972. Steps to an ecology of mind, with a new foreword by Mary Catherine Bateson. Chicago - London: University of Chicago Press. 2000.

Bhaskar, Roy. 1979. The possibility of naturalism: a philosophical critique of the contemporary human sciences. Atlantic Highlands: Humanities Press.

Bonazzi, Mauro. 2010. I sofisti. Roma: Carocci.

Buckland, Michael K. 1997. What is a "document"? Journal of the American society for information science 48n9: 804-09.

Budd, John M. 1995. An epistemological foundation for library and information science, Library journal 65n3: 295-318.

Budd, John M. 2001. Knowledge and knowing in library and information science: a philosophical framework. Lanham, Maryl. London: Scarecrow Press.

Budd, John M. 2010. Roy Bhaskar's critical realism. In Leckie, Gloria J., Given, Lisa M. and Buschman, John E., Critical theory for library and information science: exploring the social from across the disciplines. Santa Barbara, Cal.: Libraries Unlimited, 29-39.

Campbell, Donald Thomas. 1974. Evolutionary epistemology. In Schilpp, Paul Arthur, ed., The philosophy of Karl Popper. La Salle, Ill.: Open Court, 412-63.

Cappuccio, Massimiliano Lorenzo, ed. 2004. Dentro la Matrice: filosofia, scienza e spiritualità in Matrix. Milano: Albo Versorio. 
Capra, Fritjof. 1975. The Tao of physics: an exploration of the parallels between modern physics and eastern mysticism. Boulder, Cal.: Shambhala.

Cavazzoni, Ermanno. 2015. Il pensatore solitario. Parma: Guanda.

Chiodo, Simona. 2006. Visione o costruzione: Nelson Goodman e la filosofia analitica contemporanea. Milano: LED.

Dahlberg, Ingetraut. 1982. ICC - Information coding classification: principles, structure and application possibilities. International classification 9n2: 87-93.

Davies, Richard. 2004. The demon and the scientist. Epistemologia 27n2: 299-318.

De Caro, Mario and Ferraris, Maurizio, ed. 2012. Bentornata realtà: il nuovo realismo in discussione. Torino: Einaudi.

De Caro, Mario and Spinelli, Emidio, ed. 2007. Scetticismo: una vicenda filosofica. Roma: Carocci.

D’Agostini, Franca. 1999. Breve storia della filosofia nel Novecento: l'anomalia paradigmatica. Torino: Einaudi.

D’Agostini, Franca. 2013. Realismo? Una questione non controversa. Torino: Bollati Boringhieri.

Di Cesare, Donatella, Ocone, Corrado and Regazzoni, Simone, ed. 2013. Il nuovo realismo è un populismo. Genova: Il Melangolo.

Downing, Lisa. 2011. George Berkeley. In Stanford encyclopedia of philosophy, first published September 10, 2004, substantive revision January 19, 2011. Available http://plato.stanford.edu/entries/berkeley/.

Dux, Günter. 2011. Historico-genetic theory of culture: on the processual logic of cultural change. Bielefeld: Transcript.

Eco, Umberto. 2012. Di un realismo negativo. In De Caro and Ferraris, 2012, pp. 91-112.

Ferraris, Maurizio. 2009. Documentality: why it is necessary to leave traces, translated by Richard Davies. New York: Fordham University Press, 2013. Original edition: Documentalità: perché è necessario lasciar tracce. Roma - Bari: Laterza, 2009.

Ferraris, Maurizio. 2012. Manifesto of new realism, translated by Sarah De Sanctis, foreword by Graham Harman. Albany: State University of New York, 2014. Original edition: Manifesto del nuovo realismo. Roma - Bari: Laterza, 2012.

Ferrini, Cinzia. 2007. Modernità di una storia antica: Kant, Hegel e lo scetticismo. In De Caro and Spinelli, 2007, $121-145$.

Feyerabend, Paul Karl. 1999. Conquest of abundance: a tale of abstraction versus the richness of being, edited by Bert Terpstra. Chicago: University of Chicago Press, paperback edition 2001.

Gabriel, Markus. 2013. Why the world does not exist, translated by Gregory S. Moss. Cambridge: Polity, 2015. Original edition: Warum es die Welt nicht gibt. Berlin: Ullstein, 2013.

Gemes, Ken. 2013. Life's perspectives. In Gemes, Ken and Richardson, John, ed., The Oxford handbook of Nietzsche. Oxford: Oxford University Press, 553-575.

Gnoli, Claudio. 2008. L’organizzazione della conoscenza e i suoi fondamenti. In Gnoli and Scognamiglio, 2008, 69-137.

Gnoli, Claudio. 2012a. Due categorie di documenti e raccolte: il contributo dell'ontologia. Bibliotime 15n1. Available http://www .aib.it/aib/sezioni/emr/bibtime/num-xv-1/gnoli.htm.

Gnoli, Claudio. 2012b. Metadata about what? Distinguishing between ontic, epistemic, and documental dimensions in knowledge organization. Knowledge organization 39n4: 268-75.

Gnoli, Claudio. 2013. Knowledge organization for its own sake: relationships between theory and applications, video keynote presented at 2nd Brazilian ISKO conference, Rio de Janeiro, 27-29 May 2013. Abstract available in Dodebei, Vera and Chaves Guimarães, José Augusto, ed., Complexidade e organização do conhecimento: desafios de nosso século. Rio de Janeiro: ISKO Brasil - FUNDEPE, 2013. Available http://isko-brasil.org.br/wp-content/uploads/2013/02/Estudos-avançados-2.pdf, pp. 309, or http://mate.unipv.it/gnoli/sake.txt. Slides available http://mate.unipv.it/gnoli/sake.pdf.

Gnoli, Claudio. 2015. Knowledge organization systems (KOSs). In Koraljka Golub, Subject access to information: an interdisciplinary approach. Santa Barbara, Cal.: Libraries Unlimited, 43-65.

Gnoli, Claudio, Kleineberg, Michael, Ridi, Riccardo and Szostak, Rick. 2016. The blind knowledge organizers and the elephant: working notes on Kleineberg's levels of knowing, version 7.1. ISKO Italia, 2016.01.12. Available 
http://www.iskoi.org/ilc/elephant.php.

Gnoli, Claudio and Ridi, Riccardo. 2014. Unified theory of information, hypertextuality and levels of reality. Journal of documentation 70n3: 443-60. Preprint available http://mate.unipv.it/gnoli/jdoc2014uti.pdf.

Gnoli, Claudio and Scognamiglio, Carlo. 2008. Ontologia e organizzazione della conoscenza: introduzione ai fondamenti teorici dell'indicizzazione semantica. Lecce: Pensa Multimedia.

Goodman, Nelson. 1978. Ways of worldmaking. Indianapolis: Hackett.

Goodman, Nelson. 1984. Of minds and other matters. Cambridge, Mass.: Harvard University Press.

Goonatilake, Susantha. 1991. The evolution of information: lineages in gene, culture and artefact. London: Pinter.

Gopnik, Alison. 2009. The philosophical baby: what children's mind tell us about truth, love, and the meaning of life. London: The Bodley Head.

Hartmann, Nicolai. 1940. Der Aufbau der realen Welt: Grundriss der allgemeinen Kategorienlehre. Berlin: De Gruyter.

Hjørland, Birger. 2004. Arguments for philosophical realism in library and information science. Library trends 52n3: 488-506.

Hjørland, Birger. 2007. Information: objective or subjective/situational? Journal of the American society for information science and technology 58n10: 1448-56.

Hjørland, Birger. 2008. Core classification theory: a reply to Szostak. Journal of documentation 64n3: 333-42.

Hjørland, Birger. 2009. The controversy over the concept of "information": a rejoinder to professor Bates. Journal of the American society for information science and technology 60n3: 643.

Hjørland, Birger. 2010. Domain analysis in information science. In Bates, Marcia J. and Niles Maack, Mary, ed., Encyclopedia of library and information science, 3rd ed. Boca Raton: CRC, 1648-54.

Hjørland, Birger. 2011. Theoretical clarity is not "manicheanism": a reply to Marcia Bates. Journal of information science 37n5: 546-52.

Hjørland, Birger. 2015. Theories are knowledge organizing systems. Knowledge organization 42n2: 113-28.

Hjørland, Birger and Albrechtsen, Hanne. 1995. Toward a new horizon in information science: domain-analysis. Journal of the American society for information science 46n6: 400-25.

Hjørland, Birger and Hartel, Jenna. 2003. Afterword: ontological, epistemological and sociological dimensions of domains. Knowledge organization 30n3/4: 239-45.

Hofkirchner, Wolfgang. 2010. Twenty questions about a unified theory of information: a short exploration into information from a complex systems view. Litchfield Park: Emergent Publications.

Irwin, William, ed. 2002. The Matrix and philosophy: welcome to the desert of the real. Chicago: Open Court.

Irwin, William, ed. 2005. More Matrix and philosophy: Revolutions and Reloaded decoded. Chicago: Open Court.

ISKOI. 2004. Integrative levels classification. ISKO Italia, 2004.06.03-2014.05.15. Available http://www.iskoi.org/ilc/.

ISKOI. 2007. The León manifesto. ISKO Italia, 2007.04.23-2011.07.19. Available http://www.iskoi.org/ilc/leon.php.

Jones, William and Teevan, Jaime, ed. 2007. Personal information management. Seattle - London: University of Washington Press.

Juarrero, Alicia and Rubino, Carl A. 2008. Emergence, complexity and self-organization: precursors and prototypes. Goodyear: ISCE.

Kant, Immanuel. 1781/1787. Kritik der reinen Vernunft. Riga: Hartknoch, 1st edition 1781, 2nd edition 1787.

Kleineberg, Michael. 2013. The blind men and the elephant: towards an organization of epistemic contexts. Knowledge organization 40n5: 340-62. 
Kleineberg, Michael. 2014. The blind elephant: a reply to Claudio Gnoli's comments, updated version February 10, 2014. ISKO Italia. Available http://www.iskoi.org/ilc/elephant2.pdf.

Kleineberg, Michael. 2016. From linearity to co-evolution: on the architecture of Nicolai Hartmann's levels of reality. In Peterson, Keith and Poli, Roberto, ed., New research on the philosophy of Nicolai Hartmann. Berlin - Boston: De Gruyter, 81-108.

Lecaldano, Eugenio. 1987. L'etica contro la morale. L'indice dei libri del mese 4n7: 33.

Lecaldano, Eugenio. 2007. Hume, i limiti dello scetticismo e le radici del naturalismo. In De Caro and Spinelli, 2007, 105-20.

Lorenz, Konrad. 1973. Die Rückseite des Spiegels: versuch einer Naturgeschichte menschlichen Erkennens. München: Piper.

Lovejoy, Arthur O. 1936. The great chain of being: a study of the history of an idea. Cambridge, Mass.: Harvard University Press.

Magni, Sergio Filippo. 2010. Il relativismo etico: analisi e teorie nel pensiero contemporaneo. Bologna: Il Mulino.

Mazzantini, Carlo and Sacchi, Dario. 2011. Solipsismo. In Melchiorre, Virgilio, ed., Enciclopedia filosofica. Milano: Bompiani, 2010-2011, 10844-47.

Metzinger, Thomas. 2009. The ego tunnel: the science of the mind and the myth of the self. New York: Basic Books.

Migliori, Maurizio. 1973. La filosofia di Gorgia: contributi per una riscoperta del sofista di Lentini. Milano: CELUC.

Nagel, Thomas. 1979. Subjective and objective. In Thomas Nagel, Mortal questions, 15th printing of 1991 Canto edition. Cambridge: Cambridge University Press, 2012, 196-213.

Nagel, Thomas. 1986. The view from nowhere. New York: Oxford University Press.

Nannini, Sandro. 2011. L'anima e il corpo: un'introduzione storica alla filosofia della mente, 2nd revised ed. Roma - Bari: Laterza.

Nietzsche, Friedrich. 1886. Jenseits von Gut und Böse: Vorspiel einer Philosophie der Zukunft. Leipzig: Naumann.

Nietzsche, Friedrich. 1887. [Fragment] 7 [60]. In Friedrich Nietzsche, Nachgelassene Fragmente 1885-1887, herausgegebeb von Giorgio Colli und Mazzino Montinari. München-Berlin: Deutscher Taschenbuch Verlag-de Gruyter, 1988, 315. English translation from Nietzsche, 1901, 267.

Nietzsche, Friedrich. 1901. The will to power, a new translation by Walter Kaufmann and Reginald John Hollingdale, edited, with commentary, by Walter Kaufmann. New York: Vintage Books, 1968. Original edition: Der Wille zur Macht: versuch einer Umwerthung aller Werthe (Studien und Fragmente), edited by Ernst Horneffer, August Horneffer and Peter Gast, with a foreword by Elisabeth Förster-Nietzsche. Leipzig: Naumann, 1901.

Piattelli Palmarini, Massimo, ed. 1984. Livelli di realtà. Milano: Feltrinelli.

Poincaré, Jules Henri. 1902. La science et l'hypothèse. Paris: Flammarion.

Poli, Roberto. 2001. The basic problem of the theory of levels of reality. Axiomathes 12n3/4: 261-83.

Poli, Roberto. 2007. Idee di scienza e livelli di realtà. Trento: UNI Service.

Popper, Karl Raimund. 1935. Logik der Forschung: zur Erkenntnistheorie der modernen Naturwissenschaft. Wien: Springer.

Popper, Karl Raimund. 1972. Objective knowledge: an evolutionary approach. Oxford: Clarendon Press.

Putnam, Hilary. 1977. Brains in a vat. In Hilary Putnam, Reason, truth and history. Cambridge: Cambridge University Press, $1981,1-21$.

Reale, Giovanni. 2004. Storia della filosofia greca e romana. Vol. 2: Sofisti, Socrate e Socratici minori. Milano: Bompiani.

Rescigno, Paola. 2012. Siamo tutti alieni ignoranti? Bibliotime 15n1. Available http://www .aib.it/aib/sezioni/emr/bibtime/num-xv1/rescigno.htm.

Ridi, Riccardo. 2010. Il mondo dei documenti: cosa sono, come valutarli e organizzarli. Roma - Bari: Laterza.

Ridi, Riccardo. 2012. Documenti e raccolte: molteplicità e complessità delle pressioni sociali. Bibliotime 15n1. Available 
http://www .aib.it/aib/sezioni/emr/bibtime/num-xv-1/ridi.htm.

Ridi, Riccardo. 2015. Livelli di irrealtà: oggettività e soggettività nell'organizzazione della conoscenza. Bibliotime 18n2. Available http://www.aib.it/aib/sezioni/emr/bibtime/num-xviii-2/ridi.htm.

Salarelli, Alberto. 2012. Sul concetto di documento. Bibliotime 15n1. Available http://www .aib.it/aib/sezioni/emr/bibtime/num-xv1/salarelli.htm.

Santarcangelo, Vincenzo and Scarpa, Raffaella, ed. 2015. Nuovo realismo: il sito ufficiale della rassegna nuovo realismo. Torino: Università di Torino. Dipartimento di filosofia. Laboratorio di ontologia. Available https://nuovorealismo.wordpress.com/.

Scognamiglio, Carlo. 2008. Ontologia filosofica e ontologia applicata. In Gnoli and Scognamiglio, 2008, 19-67.

Sedgwick, Sally, ed. 2000. The reception of Kant's critical philosophy: Fichte, Schelling, and Hegel. Cambridge: Cambridge University Press.

Severino, Emanuele. 2014. Attualismo e storia dell'Occidente. In Giovanni Gentile, L'attualismo. Milano: Bompiani, pp. 7-69.

Skrbina, David. 2005. Panpsychism in the West. Cambridge, Mass.: MIT Press.

Smiraglia, Richard P. 2012. Introduction: theory, knowledge organization, epistemology, culture. In Smiraglia, Richard P. and Lee, Hur-Li, ed., Cultural frames of knowledge. Würzburg: Ergon Verlag, 29-39.

Smiraglia, Richard P. 2014. The elements of knowledge organization. Cham: Springer.

Thornton, Stephen P. 2004. Solipsism and the problem of other minds. In Internet encyclopedia of philosophy. Available http://www.iep.utm.edu/solipsis/.

Totaro, Francesco. 2014. Una critica del Manifesto del nuovo realismo e della ontologia presupposta. In Poli, Roberto, ed., Prospettive ontologiche: realismi a confronto. Brescia: Morcelliana, 97-112.

Varzi, Achille C. 2008. Introduzione: mondo-versioni e versioni del mondo. In Nelson Goodman, Vedere e costruire il mondo, traduzione di Carlo Marletti. Roma - Bari: Laterza, pp. vii-xxiv.

Veca, Salvatore. 2012. Filosofia, contingenza e incompletezza, Rivista di filosofia 103n3: 513-29.

Whitehead, Alfred North. 1929. Process and reality, corrected edition edited by David Ray Griffin and Donald W. Sherburne. New York: Free Press, 1978.

Wilber, Ken. 2000. Sex, ecology, spirituality: the spirit of evolution, 2nd revised ed. Boston: Shambhala.

Williams, Bernard. 1985. Ethics and the limits of philosophy. Cambridge, Mass.: Oxford University Press.

Wuketits, Franz M. 1990. Evolutionary epistemology and its implications for humankind. Albany: State University of New York.

Zeng, Marcia Lei. 2008. Knowledge organization systems. Knowledge organization 35n2/3: 160-82. 